\title{
Identification of Proteins in the Postsynaptic Density Fraction by Mass Spectrometry
}

\author{
Randall S. Walikonis, ${ }^{1}$ Ole N. Jensen, ${ }^{2}$ Matthias Mann, ${ }^{2}$ D. William Provance $\mathrm{Jr},{ }^{3}$ John A. Mercer, ${ }^{3}$ and \\ Mary B. Kennedy ${ }^{1}$ \\ 1Division of Biology, California Institute of Technology, Pasadena, California 91125, 2 European Molecular Biology \\ Laboratory, D69012 Heidelberg, Germany, and 3McLaughlin Research Institute, Great Falls, Montana 59405-4900
}

Our understanding of the organization of postsynaptic signaling systems at excitatory synapses has been aided by the identification of proteins in the postsynaptic density (PSD) fraction, a subcellular fraction enriched in structures with the morphology of PSDs. In this study, we have completed the identification of most major proteins in the PSD fraction with the use of an analytical method based on mass spectrometry coupled with searching of the protein sequence databases. At least one protein in each of 26 prominent protein bands from the PSD fraction has now been identified. We found 7 proteins not previously known to be constituents of the PSD fraction and 24 that had previously been associated with the PSD by other methods. The newly identified proteins include the heavy chain of myosin-Va (dilute myosin), a motor protein thought to be involved in vesicle trafficking, and the mammalian homolog of the yeast septin protein cdc10, which is important for bud formation in yeast. Both myosin-Va and cdc10 are threefold to fivefold enriched in the PSD fraction over brain homogenates. Immunocytochemical localization of myosin-Va in cultured hippocampal neurons shows that it partially colocalizes with PSD-95 at synapses and is also diffusely localized in cell bodies, dendrites, and axons. Cdc10 has a punctate distribution in cell bodies and dendrites, with some of the puncta colocalizing with PSD-95. The results support a role for myosin-Va in transport of materials into spines and for septins in the formation or maintenance of spines.

Key words: synaptic transmission; myosin; septins; vesicle transport; signal transduction; multiprotein complex
CNS synapses are elaborately organized sites of communication between neurons. Excitatory CNS synapses feature a prominent thickening at the cytoplasmic surface of the postsynaptic membrane termed the postsynaptic density (PSD). The PSD contains receptors with associated signaling and scaffolding proteins that organize signal transduction pathways near the postsynaptic membrane. Proposed functions for PSD proteins include regulation of adhesion between presynaptic and postsynaptic membranes (Siekevitz, 1985; Apperson et al., 1996), control of postsynaptic receptor clustering and function (Siekevitz, 1985; Sheng, 1996), and signal transduction in response to receptor activation (Kennedy, 1993). The PSD fraction is a subcellular fraction highly enriched in multiprotein structures derived from PSDs (Cotman et al., 1974; Cohen et al., 1977). Separation of proteins in this fraction by SDS-PAGE reveals $\sim 15$ major and 11 minor protein bands (Kennedy, 1997). The recent identification of signaling and scaffold proteins among the major bands in the

\footnotetext{
Received Jan. 28, 2000; revised March 10, 2000; accepted March 17, 2000.

This work was supported by National Institutes of Health Grant NS28710 (M.B.K.), by a fellowship from the FRAXA Research Foundation (R.S.W.), by a fellowship from the European Union Biotechnology Program (O.N.J.), and by the European Molecular Biology Laboratory (EMBL) (O.N.J. and M.M.). We thank Anna Shevchenko (EMBL) for expert technical assistance with preparation of protein samples for mass spectrometry and Lisa Evans for advice on early experiments.

Correspondence should be addressed to Mary B. Kennedy, Division of Biology 216-76, California Institute of Technology, Pasadena, CA 91125. E-mail: kennedym@ its.caltech.edu.

Dr. Jensen's and Dr. Mann's present address: Department of Biochemistry and Molecular Biology, University of South Denmark, Odense University, DK-5230 Odense M, Denmark.

Copyright (C) 2000 Society for Neuroscience $\quad 0270-6474 / 00 / 204069-12 \$ 15.00 / 0$
}

PSD fraction confirms several of the proposed functions for PSDs (Kennedy, 1997, 1998; Ziff, 1997).

Signaling molecules that make up $\geq 1 \%$ of the total protein in the PSD fraction include the NR2A and NR2B subunits of the NMDA receptor (Moon et al., 1994), the $\alpha$ and $\beta$ subunits of $\mathrm{Ca}^{2+} /$ calmodulin-dependent protein kinase II (CaMKII) (Kennedy et al., 1983; Kelly et al., 1984; Miller and Kennedy, 1985), and synGAP, a ras GTPase-activating protein phosphorylated by CaMKII (Chen et al., 1998). Other prominent PSD proteins are scaffold molecules, including the PSD-95 family (Cho et al., 1992; Kistner et al., 1993; Brenman et al., 1996; Kim et al., 1996; Lau et al., 1996), that link receptors to signaling proteins or to the cytoskeleton, thus helping organize the structure of PSDs (Kornau et al., 1995; Kim et al., 1995, 1998; Irie et al., 1997; Chen et al., 1998). Finally, densin-180, a putative adhesion protein with extracellular and intracellular protein binding domains, is a prominent component of the PSD fraction (Apperson et al., 1996).

Despite the recent progress in identifying PSD proteins, several protein bands in the PSD fraction have remained unidentified, and the functions of the PSD are as yet incompletely understood. In the present study, we used a new method based on mass spectrometry (Jensen et al., 1997) to rapidly and systematically identify proteins in the PSD fraction by comparing their tryptic peptide profiles with those of proteins in the protein sequence databases. In addition to many previously identified PSD proteins, we identified several proteins not previously known to be constituents of the PSD fraction. Two of these, myosin-Va (dilute myosin) and the septin protein cdc10, were selected for further study because they have the most intriguing potential functions. We report that both myosin-Va and cdc10 are enriched in the 
PSD fraction and are among the more abundant proteins there. They both partially colocalize with PSD-95 at postsynaptic sites along dendrites in cultured hippocampal neurons.

\section{MATERIALS AND METHODS}

Isolation of the PSD fraction. PSD fractions were prepared from rat forebrains as previously described (Carlin et al., 1980; Cho et al., 1992). Synaptosomes were isolated from homogenates by differential and density gradient centrifugation and then extracted with $0.5 \%$ Triton X-100 for $15 \mathrm{~min}$. The resulting "One-Triton" PSD fraction was pelleted by centrifugation at $36,800 \times g$ for $45 \mathrm{~min}$. A portion of the One-Triton fraction was extracted again either with $0.5 \%$ Triton X-100 for 15 min or with $3 \% \mathrm{~N}$-lauroyl-sarcosine for $10 \mathrm{~min}$ and then pelleted by centrifugation at $201,800 \times g$ for $1 \mathrm{hr}$ to obtain the "Two-Triton" PSD fraction or the "One-Triton plus Sarcosyl" PSD fraction, respectively. Protein concentrations were determined by a modified method of Lowrey (Peterson, 1983).

Identification of proteins in the PSD fraction by mass spectrometry. Protein identification was performed by mass spectrometry combined with sequence database searches (Jensen et al., 1998). Protein bands cut from a Coomassie blue-stained polyacrylamide gel were rinsed, reduced, $S$-alkylated, and then incubated with trypsin (Shevchenko et al., 1996b). The resulting tryptic peptide mixtures were directly analyzed by matrixassisted laser desorption/ionization reflector time-of-flight mass spectrometry (MALDI-TOF-MS) (Jensen et al., 1996). Peptide mass spectra displayed up to 150 peptide ion signals for some of the larger proteins in the PSD fraction. The MALDI-TOF mass spectrometer (REFLEX; Bruker Daltonics, Bremen, Germany) was operated in the delayed extraction, positive ion mode. Samples were prepared according to the fast evaporation deposition method using $\alpha$-cyano-4-hydroxycinnamic acid and nitrocellulose as the matrix (Vorm et al., 1994; Jensen et al., 1996). Ion signals produced by trypsin autodigestion peptides, which were present in all peptide mass spectra, were used for internal mass calibration. Peptide mass errors were typically in the range of $15-25 \mathrm{ppm}$.

Proteins were identified by searching databases with lists of tryptic peptide masses (peptide mass maps) generated from the proteins by MALDI-TOF MS. PeptideSearch or ProFound software (accessible on the Internet via http://www.protein.sdu.dk) was used to query nonredundant protein sequence databases with peptide mass data. Protein mixtures of up to five proteins were resolved by iterative database searches as described (Jensen et al., 1997).

Cloning of the cDNA encoding rat cdc10. Oligonucleotide primers were designed based on the nucleotide sequence of human cdc10 (hcdc10; GenBank accession number S72008). First-strand cDNAs were prepared from 5-week-old rat forebrain poly $\left(\mathrm{A}^{+}\right)$RNA with the RT-for-PCR kit (Clontech, Palo Alto, CA). PCR was conducted in $1 \times$ Taq buffer (supplied with the Taq) plus $50 \mu \mathrm{M}$ sense and antisense primers, $2 \mathrm{~mm}$ dNTPs, $2.5 \mathrm{U}$ of Taq, and $4 \mathrm{ng} / \mu \mathrm{l}$ cDNA. A single fragment of $419 \mathrm{bp}$ was amplified with a sense primer corresponding to hodc10 bp 22-39 (5'GAGGAGAGGAGCGTCAAC-3') and an antisense primer corresponding to hedc10 bp 422-441 (5'-CTGTTCACTCGTGATTCTG-3'). The product of the PCR reaction was ligated into the TA vector pCR2.1 and transformed into $\mathrm{INV}_{\alpha} \mathrm{F}^{\prime}$ cells (Invitrogen, San Diego, CA). The cells were grown overnight, and the plasmids isolated with QIAprep Spin Miniprep columns (Qiagen, Chatsworth, CA). The DNA inserts were sequenced on an automatic DNA sequencer in the Caltech DNA Microsequencing Facility.

We screened a $\gamma \mathrm{gt11}$ rat brain cDNA library (Clontech) for clones hybridizing to the cdc10 PCR product. A single $1041 \mathrm{bp}$ clone and two copies of a 1116 bp clone were isolated and sequenced. The $5^{\prime}$ end of all three clones begins at an EcoRI site homologous to hedc10 bp 140. The $3^{\prime}$ end of the 1116 bp clones encodes a second EcoRI site that is absent in hcdc10. Neither of the cDNAs contained the complete coding region, so we used a strategy based on PCR to find the remaining coding sequence. The $5^{\prime}$ end of the rat cdc10 sequence was amplified by PCR with a sense primer (5'-GGGCGGCCTACGCTGCGGAATCGG-3' or 5'-CGTAGGTGGTTTTGGAGAATC-3') matching sequences upstream from the mouse cdc10 start site (Soulier and Vilotte, 1998) and with the 422-441 antisense primer listed above. The $3^{\prime}$ coding region was amplified with sense primers matching bp 5-24 (5'-CGAGATCCGCTGCTGCTGAG$\left.3^{\prime}\right)$, bp 852-871 (5'-TATGAAGATAAGAACACACA-3'), and bp 911931 (5'-AGAACTACGAAGCAGAAAAC - $\left.3^{\prime}\right)$ of hcdc10 and an antisense primer matching bp 1379-1399 of hcdc10 (5'-AACTGGTGCAAATGGTCAAA-3'). Each PCR reaction gave a single product of the appropriate size. The PCR products were ligated into the TA vector and sequenced in both directions. The portions of the reported sequence of rat cdc10 that were based on results of PCR amplification were derived from the sequences of at least four independent PCR products. The overlapping sequences were assembled with Sequencher software (Gene Codes Corp., Ann Arbor, MI) into a 1494 bp sequence containing the complete coding regions of rat cdc10.

Construction of fusion proteins and preparation of antisera. A glutathione $S$-transferase (GST):myosin-Va fusion construct was made by inserting a 2439 bp cDNA encoding amino acids 1042-1854 of mouse myosin-Va heavy chain (Seperack et al., 1995) into pGEX-5X-2 (Pharmacia Biotech, Piscataway, NJ). We prepared two GST:cdc10 fusion proteins in pGEX-5X-1. One contained base pairs 238-538 (encoding amino acids 49-148); the other contained base pairs 238-1352 (encoding amino acids 49-420). The proper orientation of insertion for each construct was verified by restriction digestion and sequencing. Fusion proteins were produced in Escherichia coli DH5 $\alpha$. After transformation, the cells were grown at $30^{\circ} \mathrm{C}$ to an optical density of 0.5 at $600 \mathrm{~nm}$, and expression of GST fusion proteins was induced by addition of $0.1 \mathrm{~mm}$ isopropyl- $\beta$-D-thiogalactopyranoside for $5 \mathrm{hr}$ at $30^{\circ} \mathrm{C}$. The cells were pelleted by centrif ugation at $5000 \times g$ for $10 \mathrm{~min}$ and resuspended in PBS plus protease inhibitors (20 mM sodium phosphate, $\mathrm{pH} 7.4$, and $0.15 \mathrm{M}$ $\mathrm{NaCl}$ containing $0.5 \mathrm{~mm}$ dithiothreitol, $1 \mathrm{~mm}$ EDTA, $1 \mathrm{~mm}$ EGTA, 20 $\mu \mathrm{g} / \mathrm{ml}$ aprotinin, $5 \mu \mathrm{g} / \mathrm{ml}$ antipain, and $0.4 \mu \mathrm{g} / \mathrm{ml}$ pepstatin; $17 \mu \mathrm{g} / \mathrm{ml}$ of PMSF was added at each extraction step). The suspended cells were lysed by sonication [ 2 min, level $5,50 \%$ cycle with a Branson (Danbury, CT) 450 Sonifier]. Triton X-100 was added to a final concentration of $1 \%$, and the solution was stirred for $10 \mathrm{~min}$. Lysates were cleared by centrifugation at $15,000 \times g$ for $10 \mathrm{~min}$. The supernatant was saved on ice, and the pellet was resuspended in PBS plus protease inhibitors. $N$-Lauroyl sarcosine was added to a final concentration of $1 \%$, and the suspension was sonicated as above. Triton X-100 was again added to a final concentration of $1 \%$, and the lysate was cleared by centrifugation as above. The two supernatants were pooled, $2 \mathrm{ml}$ of glutathione-conjugated agarose beads (Sigma, St. Louis, MO) was added, and the solution was rotated end over end for $10 \mathrm{~min}$ at room temperature. The supernatant was decanted, and the beads were washed three times with PBS. The GST fusion proteins were eluted overnight in $50 \mathrm{~mm}$ Tris, $\mathrm{pH} 8.0,20 \mathrm{~mm}$ glutathione, and 1\% Triton X-100, and the supernatant was removed after centrifugation to remove the beads.

The eluted fusion proteins $(\sim 10 \mu \mathrm{g} /$ injection $)$ were injected into Swiss-Webster mice to generate polyclonal ascites fluid (Ou et al., 1993). The specificity of the antibodies was tested by immunoblotting against both purified fusion proteins and brain homogenates. Two mice produced antibodies specific for myosin-Va (antibodies DB1-B and DB1-C). Three mice inoculated with the cdc10 47-149 construct produced antibodies specific for cdc10 (antibodies N1, D1, and D2), as did three mice inoculated with the cdc10 47-420 fusion protein (antibodies L1, L2, and L3). Ascites fluids were partially purified by $50 \%$ ammonium sulfate precipitation overnight at $4^{\circ} \mathrm{C}$, resuspended, and dialyzed against $25 \mathrm{~mm}$ Tris, $\mathrm{pH}$ 7.5. The concentration of IgG was estimated by comparison with mouse IgG standards on Coomassie blue-stained gels (DB1-C, $2 \mu \mathrm{g} / \mu \mathrm{l}$; $\mathrm{L} 2,1.5 \mu \mathrm{g} / \mu \mathrm{l})$.

Immunocytochemical labeling of dissociated hippocampal neurons. Cultures of hippocampal neurons from embryonic day 18 rats were grown on poly-D-lysine- and laminin-coated coverslips at a density of $\sim 200 / \mathrm{mm}^{2}$ (Brewer et al., 1993; Apperson et al., 1996). After 3-5 weeks in vitro, the coverslips were removed from the culture media, washed in HBSS with 10 mM HEPES, pH 7.4, and fixed with $-20^{\circ} \mathrm{C}$ methanol for $20 \mathrm{~min}$. The fixed cells were rehydrated with HBSS and incubated in preblock buffer (20 mm phosphate buffer, $\mathrm{pH} 7.4,5 \%$ normal goat serum, $0.05 \%$ Triton $\mathrm{X}-100$, and $450 \mathrm{~mm} \mathrm{NaCl}$ ) for $1 \mathrm{hr}$ at $4^{\circ} \mathrm{C}$. They were then incubated overnight at $4^{\circ} \mathrm{C}$ with either DB1-C antibodies at a 1:400 dilution or L2 antibodies at a 1:200 dilution. Polyclonal rabbit antibodies against PSD-95 (Cho et al., 1992) were added at a dilution of 1:500. The cultures were washed in preblock solution, and $\mathrm{Cy3}$-conjugated goat anti-mouse secondary antibodies and FITC-conjugated goat anti-rabbit antibodies were added at a dilution of 1:100 in preblock buffer and incubated for 1 $\mathrm{hr}$ at room temperature. Coverslips were washed once in preblock buffer and twice in PBS and then post-fixed for 10 min with $2 \%$ paraformaldehyde. The coverslips were rinsed twice with PBS and twice with 0.1 mm sodium bicarbonate, $\mathrm{pH} 9.2$, and then mounted on slides with $90 \%$ glycerol, 4\% n-propyl gallate, and 0.1 m sodium bicarbonate, $\mathrm{pH}$ 9.2. The immunostained cells were viewed using a Zeiss (Thornwood, NY) LSM310 fluorescence laser-scanning confocal microscope. A $63 \times$ oil 


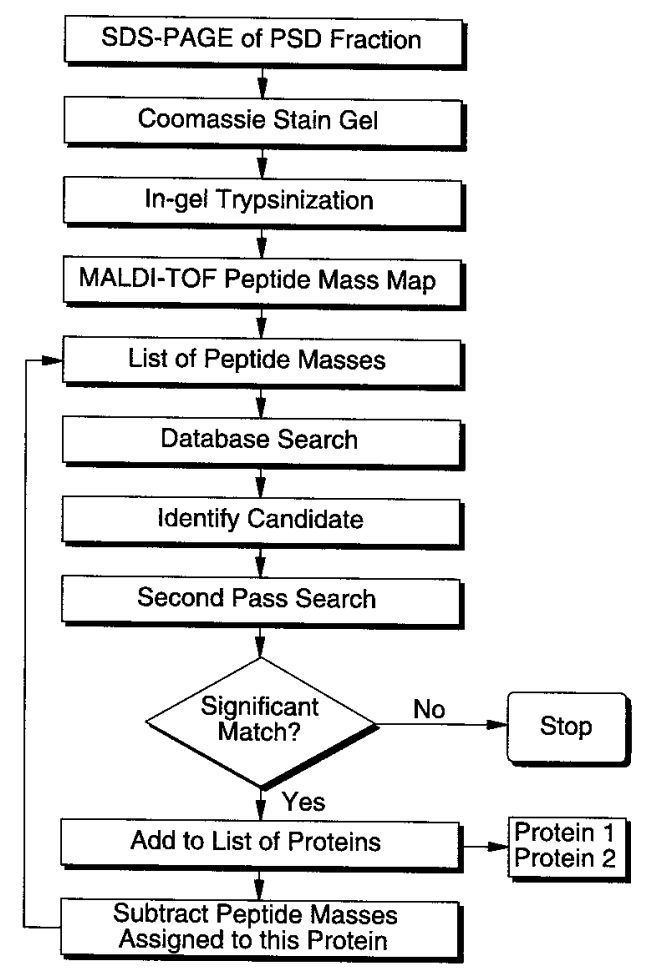

Figure 1. Strategy for identifying proteins in the PSD fraction by MALDI-TOF mass spectrometry. The masses of tryptic peptides derived from individual protein bands in an SDS-PAGE gel are compared with theoretical masses of tryptic peptides for each protein in the database.

immersion objective was used at electronic zoom factors from 1 to 2 . Images were scanned for $64 \mathrm{sec}$ using contrast settings from 320 to 410 and brightness settings from 9600 to 9700 . Images were aligned and colorized with Adobe (Mountain View, CA) Photoshop without adjusting the original data.

For control immunolabeling, the DB1-C and L2 antisera were preabsorbed with their respective antigens before application to cultures. Each antiserum was mixed with the appropriate GST fusion protein at a ratio of $1 \mathrm{~mol}$ of $\mathrm{IgG}$ to $3 \mathrm{~mol}$ of antigen.

Immunoblots. Forebrain homogenate, synaptosomes, and detergentextracted PSD fractions were separated by SDS-PAGE under reducing conditions and electrophoretically transferred to nitrocellulose membranes. The membranes were blocked at least $2 \mathrm{hr}$ in $5 \%$ nonfat milk in TBST (10 mM Tris, pH 7.5, $200 \mathrm{~mm} \mathrm{NaCl}$, and 0.2\% Tween 20) and incubated with DB1-C antibodies (diluted 1:1500) or L2 antibodies (diluted 1:1000) for $5 \mathrm{hr}$. Bound antibodies were detected by the alkaline phosphatase method using secondary antibodies purchased from Boehringer Mannheim (Indianapolis, IN).

\section{RESULTS}

\section{Strategy for identification of proteins in the PSD fraction by MALDI-TOF mass spectrometry}

To identify proteins in the PSD fraction, the Two-Triton PSD fraction $(30 \mu \mathrm{g})$ was fractionated by SDS-PAGE, and proteins were stained with Coomassie blue. The gel was photographed, and 26 individual protein bands were coded for study. Individual protein bands were then excised and digested with trypsin in the gel (Rosenfeld et al., 1992; Jeno et al., 1995; Shevchenko et al., 1996a). The mass-to-charge ratio of the peptides released from the gel was measured by MALDI-TOF MS with high mass accuracy (Jensen et al., 1996). The complete set of peptide masses from each protein band was then compared with the tryptic peptide masses predicted for each protein in a comprehensive nonredundant database (Fig. 1).
A protein from the PSD fraction was considered identified when the spectrum of its measured peptide masses met the previously established criteria for positive identification of proteins using MALDI-TOF MS and automated database searching (Jensen et al., 1997). First, to distinguish a valid match from a false positive, a minimum of five measured peptide masses must match tryptic peptide masses calculated for an individual protein in the database, with $<50$ ppm deviation in mass between measured and calculated values. Second, the peptides identified by these matches must provide at least $15 \%$ sequence coverage of the identified protein. Other criteria are also considered, such as the percentage of the total number of observed peaks that can be assigned to a putative match and the similarity in molecular weight of the unknown protein to the putative match. It is important to note that multiple proteins comigrating in a single band can be identified by removing the peptide masses assigned to the first identified protein from the complete list of masses and using the remaining list of masses to rescan the database (Jensen et al., 1997).

For this study, we searched the database for proteins with a mass range of $0-700 \mathrm{kDa}$ for large proteins (apparent $M_{\mathrm{r}}>200$ $\mathrm{kDa}$ by SDS-PAGE) and 0-300 kDa for the smaller proteins, with no constraint on species of origin. After the initial identification of a protein, a "second pass search" was conducted. In this step, incomplete tryptic cleavage and peptide modifications that may alter the peptide masses, such as oxidized methionine or $S$-acrylamidocysteine, were calculated for the putatively identified protein and compared with the measured masses. The modified peptides identified in the second pass search were added to the list generated in the first pass search to increase the number of matching peptides and sequence coverage.

\section{Identification of myosin-Va (dilute myosin)}

Figure 2 illustrates the peptide mass map of a previously unidentified protein band in the PSD fraction containing proteins of apparent mass $190 \mathrm{kDa}$. The complete set of peptide masses from this band was found to contain peptides from two proteins. Thirty-six of the measured peptide masses matched theoretical tryptic peptide masses calculated for the heavy chain of the unconventional myosin, myosin-Va, (also called dilute myosin; accession number Q99104), a protein with a predicted mass of $215 \mathrm{kDa}$ (Table 1). The matching peptides cover 451 of 1853 amino acids, or $24 \%$ of the myosin-Va sequence. The peptide masses exclude a match with the homologous protein myosin-Vb, illustrating the power of this technique to unambiguously identify a protein isoform. The peptide masses assigned to myosin-Va were then removed from the mass spectrum list, and the database was queried with the remaining masses. Twenty-three of the remaining peptides were assigned to the abundant PSD protein $\alpha$ II-spectrin (accession number X90845), also called fodrin (Glenney et al., 1982). Myosin-Va migrates faster than full-length $\alpha$ II-spectrin. However, apparently because $\alpha$ II-spectrin is a particularly abundant protein in the Two-Triton PSD fraction, peptides from $\alpha \mathrm{II}$-spectrin were detected in the digest of the myosin-Va band as well as in digests of several other protein bands of lower molecular weight.

\section{Identification of cdc10}

Figure 3 illustrates the peptide mass map of a previously unidentified PSD protein band in the PSD fraction containing a protein of apparent mass $45 \mathrm{kDa}$. Eleven peptide masses matched the theoretical peptide masses calculated for the mouse septin protein 
Figure 2. MALDI-TOF peptide mass map obtained from a $190 \mathrm{kDa}$ protein band in the PSD fraction. Ion signals with measured masses that match calculated masses of protonated tryptic peptides of myosin-Va $(\bullet)$ and $\alpha$ II-spectrin ( $\square$ ) within $50 \mathrm{ppm}$ are indicated. $T$, Signals from autolysis products of trypsin; $M$, signals from matrix-related ions.

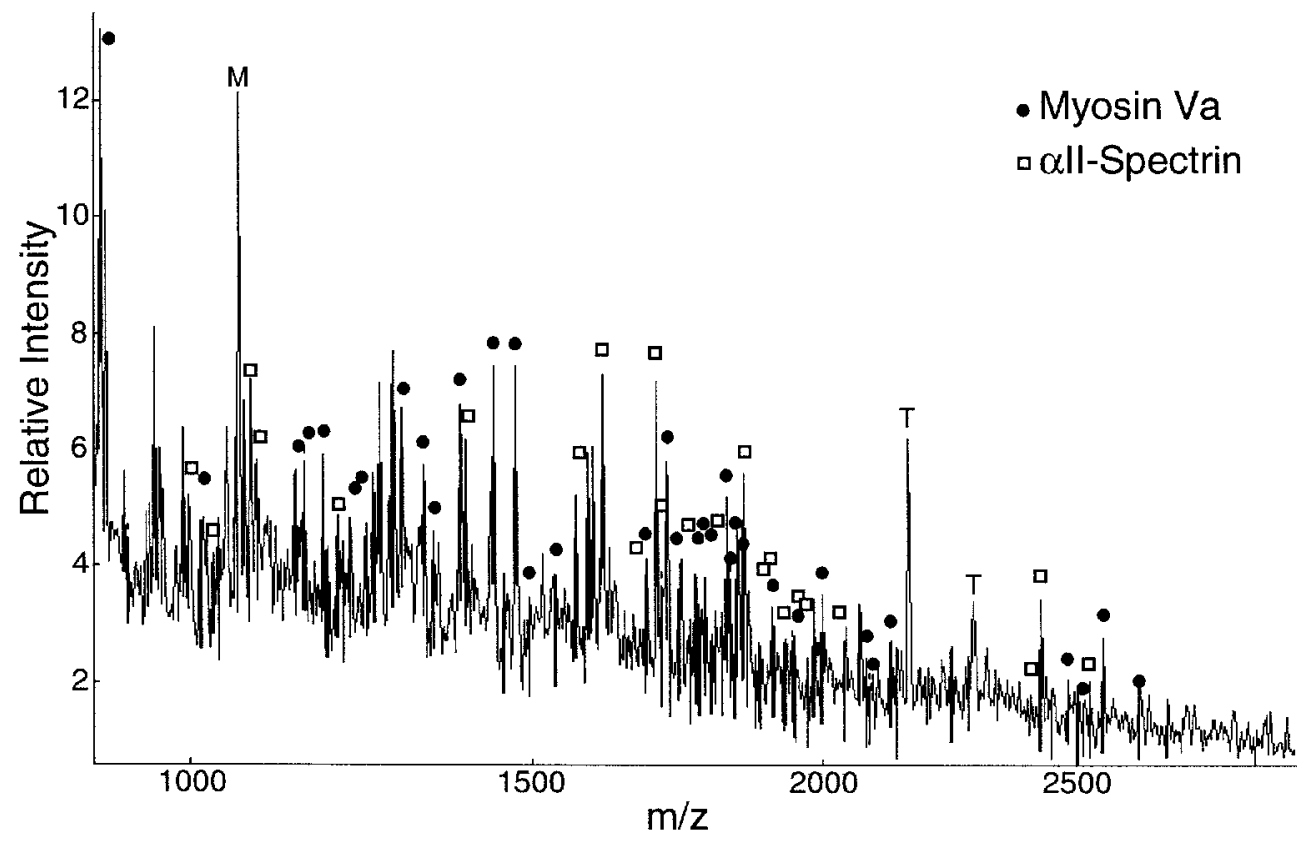

cdc10 (accession number O55131), a protein with a predicted mass of $48-50 \mathrm{kDa}$. The matching peptides cover 136 of 436 amino acids, or $31 \%$ of the sequence (Table 2). Septins are a family of proteins that form membrane-associated filaments that recruit other proteins to establish specialized domains (Field and Kellogg, 1999). They play well established roles in formation of the yeast bud site and neck constriction before cytokinesis (see Discussion).

Because no cdc10 ortholog had yet been isolated from rat, we screened a $\lambda \mathrm{gt} 11$ rat brain cDNA library with a fragment of cdc10 obtained by PCR amplification from first-strand adult rat cDNAs. We isolated two identical 1116 bp clones and one 1041 bp clone, the sequence of which was entirely contained in the longer clones. The clones contained all of the coding region for rat cdc10 except $144 \mathrm{bp}$ at the $5^{\prime}$ end and $50 \mathrm{bp}$ at the $3^{\prime}$ end. The sequences of these regions were obtained after their amplification by PCR (see Materials and Methods), and the complete 1494 bp sequence was assembled and submitted to GenBank (accession number AF142759). The 1310 bp continuous open reading frame contains a potential alternative initiation codon $57 \mathrm{bp}$ after the first. The DNA sequence of the second potential initiation codon better fits the sequence defined by Kozak $(1989,1997)$. However, initiation of translation may potentially occur at either start site to give proteins of either 419 or 436 aa, with predicted masses of 48.6 or $50.5 \mathrm{kDa}$. The deduced amino acid sequence of rat cdc10 is $>99 \%$ identical to that of mouse, with only a Gly to Ser substitution at residue 18 and a Glu to Gly substitution at residue 216. The sequences of the mouse cdc10 peptides that were matched in the MALDI-TOF MS experiments are identical to those of rat cdc10.

\section{Myosin-Va and cdc10 are enriched in the PSD fraction}

One criteria that we have used to assess the specificity of association of a protein with the PSD fraction is its enrichment in the PSD fraction compared with forebrain homogenate and synaptosomes (Cho et al., 1992; Apperson et al., 1996). We raised antisera against fusion proteins containing GST and C-terminal sequences of myosin-Va or cdc10 as described in Materials and Methods. The antisera recognize protein bands of the correct molecular weights on immunoblots of forebrain homogenates (Fig. $4 A, B$ ). The doublet of $\sim 48-50 \mathrm{kDa}$ recognized by the antibody against cdc10 may arise from initiation at both of the two potential initiation sites in the cdc10 message. Immunoblots of forebrain homogenates $(\mathrm{FBH})$, synaptosomes, and One-Triton and Two-Triton PSD fractions with anti-myosin-Va revealed a single band of $190 \mathrm{kDa}$ in each fraction, with myosin-Va enriched approximately threefold in the PSD fractions compared with FBH (Fig. 4A). Similar immunoblots with anti-cdc10 revealed that it is enriched approximately fivefold in the PSD fractions compared with FBH (Fig. 4B). Some cdc10 remains in the sarcosyl-treated PSD fraction, although it is significantly diminished compared with the One-Triton and Two-Triton PSD fractions. The fold enrichment of these two proteins in the PSD fraction is not as large as that of PSD-95 (Cho et al., 1992), densin-180 (Apperson et al., 1996), or the NR2B subunit of the NMDA receptor (Moon et al., 1994), each of which is enriched $\sim 10$ - to 30 -fold in the PSD fraction compared with FBH, and each of which is localized nearly exclusively at synapses in dendrites of cultured hippocampal neurons (Kornau et al., 1995; Apperson et al., 1996). The threefold to fivefold enrichments of myosin- Va and cdc10 in the PSD fraction suggest that they may be concentrated at the PSD, but that significant portions of the two proteins are also located elsewhere in neurons or glia.

\section{Myosin-Va and cdc10 are located at synapses in cultures of dissociated hippocampal neurons}

We investigated the subcellular location of myosin-Va and cdc10 by fluorescence immunocytochemistry. Dissociated hippocampal neurons plated at embryonic day 18 (E18) and grown in culture for 3-5 weeks were double-stained with antibodies against either myosin-Va or cdc10 and the PSD protein PSD-95 as described in Materials and Methods. High-resolution imaging with the laser scanning confocal microscope revealed that both myosin-Va and cdc10 partially colocalize with PSD-95 at discrete sites on dendrites (Fig. 5A,B). The myosin-Va and cdc10 antibodies also stain the neuronal cell body. Diffuse myosin-Va staining is visible throughout dendritic shafts and in axons, which form a network of fine processes around the thicker dendrites. Staining for cdc10 is 


\begin{tabular}{|c|c|c|c|}
\hline Measured mass & Calculated mass & Myosin-Va residues & Amino acid sequence ${ }^{a}$ \\
\hline 887.447 & 887.458 & $1220-1226$ & $(\mathrm{~K}) \mathrm{NELNELR}(\mathrm{K})$ \\
\hline 1014.637 & 1014.621 & $776-783$ & (K)TIRGWLLR(K) \\
\hline 1140.631 & 1140.605 & $223-231$ & (K)YIEIGFDKR(Y) \\
\hline 1154.483 & 1154.518 & $1051-1059$ & (K)EMTETMERK(L) \\
\hline 1180.641 & 1180.584 & 1088-1096 & (R)LEERYDDLK(E) \\
\hline 1245.673 & 1245.651 & $1810-1820$ & (R)KDSPQLLMDAK(H) \\
\hline 1255.688 & 1255.675 & $1188-1197$ & (K)AKEEERPQIR(G) \\
\hline 1296.711 & 1296.691 & $1370-1380$ & (R)IEASLQHEITR(L) \\
\hline 1329.719 & 1329.748 & $1321-1331$ & (R)LLESQLQSQKR(S) \\
\hline 1386.751 & 1386.775 & $873-883$ & (R)VRGWLARTHYK(R) \\
\hline 1344.721 & 1344.699 & $824-832$ & (K)YWRM*YVVRR(R) \\
\hline 1436.709 & 1436.717 & $1719-1729$ & (R)YNVSQLEEWLR(D) \\
\hline 1472.776 & 1472.790 & $220-231$ & (R)FGKYIEIGFDKR(Y) \\
\hline 1494.761 & 1494.756 & $535-546$ & (K)C $\mathrm{C}^{\mathrm{a}} \mathrm{ALFEKPRMSNK}(\mathrm{A})$ \\
\hline 1535.812 & 1535.868 & $380-393$ & (K)LATATETYIKPISK(L) \\
\hline 1688.005 & 1687.993 & $1148-1161$ & (K)VPLDMSLFLKLQKR(V) \\
\hline 1722.889 & 1722.870 & $1780-1793$ & (K)VLNLYTPVNEFEER(V) \\
\hline 1727.889 & 1727.958 & $677-691$ & (R)AVQQLRAC AV GETIR(I) \\
\hline 1771.853 & 1771.917 & $10-23$ & (K)FARVWIPDPEEVWK(S) \\
\hline 1788.874 & 1788.829 & 179-195 & (R)YFATVSGSASEANVEEK(V) \\
\hline 1826.980 & 1827.001 & $37-51$ & (K)VLLLHLEEGKDLEYR(L) \\
\hline 1832.921 & 1832.971 & $156-174$ & (R)NQSIIVSGESGAGKTVSAK(Y) \\
\hline 1841.847 & 1841.913 & $1648-1664$ & (R)TSSIADEGTYTLDSILR(Q) \\
\hline 1847.033 & 1847.013 & $1354-1369$ & (R)QQQLLAQNLQLPPEAR(I) \\
\hline 1853.909 & 1853.898 & $1051-1065$ & (K)EMTETMERKLVEETK(Q) \\
\hline 1909.932 & 1909.850 & $1583-1597$ & (R)QNEHCLTNFDLAEYR(Q) \\
\hline 1947.901 & 1947.854 & $1546-1561$ & (R)GDDFETVSFWLSNTC ${ }^{a}$ R(F) \\
\hline 1998.999 & 1998.972 & $1287-1303$ & (K)NTM*TDSTILLEDVQKM*K(D) \\
\hline 2001.971 & 2002.030 & $884-898$ & (K)RTMKAIVYLQCCFRR(M) \\
\hline 2082.044 & 2081.991 & $1284-1301$ & (K)DDKNTM*TDSTILLEDVQK(M) \\
\hline 2089.948 & 2089.940 & $1545-1561$ & (K)RGDDFETVSFWLSNTCR(F) \\
\hline 2129.058 & 2128.975 & $290-309$ & (K)QGGSPMIEGVDDAKEMAHTR(Q) \\
\hline 2480.246 & 2480.197 & $587-609$ & (K)MLPELFQDDEKAISPTSATSSGR(T) \\
\hline 2513.372 & 2513.270 & $1468-1487$ & (K)EKDFQGMLEYKREDEQKLVK(N) \\
\hline 2553.202 & 2553.229 & $1332-1353$ & (R)SHENEAEALRGEIQSLKEENNR(Q) \\
\hline 2630.273 & 2630.382 & $30-51$ & (K)DYKPGDK VLLLHLEEGKDLEYR(L) \\
\hline
\end{tabular}

${ }^{a} \mathrm{M}^{*}$, Methionine sulfoxide; $\mathrm{C}^{\mathrm{a}}, S$-acrylamidocysteine.

also visible in the shafts, but only as discrete puncta that do not colocalize with PSD-95. Thus neither myosin-Va nor cdc10 is exclusively confined to synapses.

Control cultures were stained with primary antibodies against myosin-Va or cdc10 that had been preabsorbed with the appropriate antigen as described in Materials and Methods. Under these conditions, almost no staining was visible; therefore Figure 5 accurately represents the subcellular distributions of the two proteins.

\section{Additional proteins identified in the Two-Triton PSD fraction}

Twenty-six protein bands of the Two-Triton PSD fraction were analyzed as above by tryptic digestion followed by MALDI-TOF MS and an automated search of the database. Thirty-one individual proteins, including myosin-Va and cdc10, were identified and assigned to specific protein bands (Fig. 6A,B).

Several signaling proteins previously identified in the PSD fraction by microsequencing or by other biochemical methods were also found in this study (Fig. 6B): NR1 and NR2B subunits of the NMDA-type glutamate receptor (Moon et al., 1994); the $\alpha$ and $\beta$ subunits of CaMKII (Kennedy et al., 1983; Kelly et al., 1984; Miller and Kennedy, 1985); synGAP, a synapse-specific Ras GTPase-activating protein (Chen et al., 1998; Kim et al., 1998); citron, a target for Rac GTPases (Zhang et al., 1999); and an insulin receptor tyrosine kinase $53 \mathrm{kDa}$ substrate protein (Yeh et al., 1996; Abbott et al., 1999). Each of these proteins has previously been localized by immunocytochemistry to synapses in dissociated hippocampal neurons (Kennedy et al., 1990; Kornau et al., 1995; Chen et al., 1998; Kennedy, 1998; Kim et al., 1998; Abbott et al., 1999; Zhang et al., 1999).

Similarly, we identified scaffold and cytoskeletal proteins that have been identified previously in the PSD fraction by other methods. These proteins include scaffold proteins PSD-95 (Cho et al., 1992; Kistner et al., 1993; Kornau et al., 1995) and homer (Brakeman et al., 1997; Kato et al., 1997, 1998; Naisbitt et al., 1999; Tu et al., 1998, 1999) and cytoskeletal proteins, $\alpha$-actinin (Wyszynski et al., 1997, 1998), bassoon (tom Dieck et al., 1998), $\alpha$ II- and $\beta$-spectrin (Carlin et al., 1983), $\beta$-actin (Kelly and Cot- 
Figure 3. MALDI-TOF peptide mass map obtained from a $45 \mathrm{kDa}$ protein band in the PSD fraction. Ion signals with measured masses that match calculated masses of mouse cdc10 (๑) within $50 \mathrm{ppm}$ are indicated. $T$, Signals derived from autolysis products of trypsin.

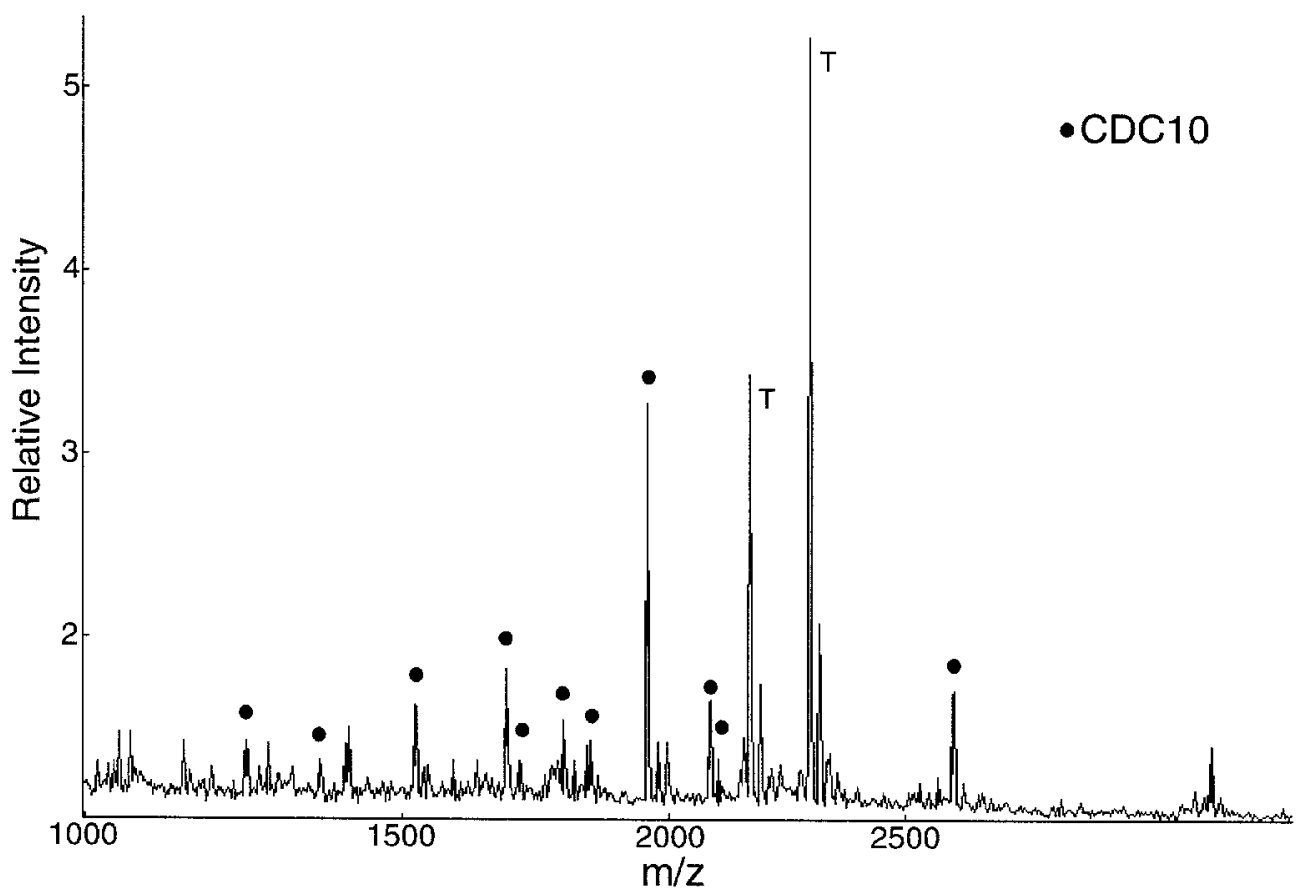

\begin{tabular}{|c|c|c|c|}
\hline Measured mass & Calculated mass & CDC10 residues & Amino acid Sequence ${ }^{a}$ \\
\hline 1243.545 & 1243.559 & $137-146$ & (K)FEDYLNAESR(V) \\
\hline 1361.576 & 1361.648 & $333-343$ & $(\mathrm{~K}) \mathrm{SPLAQM}{ }^{*} \mathrm{EEERR}(\mathrm{E})$ \\
\hline 1523.622 & 1523.687 & 298-309 & (K)DVTNNVHYENYR(S) \\
\hline 1686.778 & 1686.841 & $47-62$ & (R)GFEFTLM*VVGESGLGK(S) \\
\hline 1708.763 & 1708.821 & $195-208$ & (K)ADTLTPEEC ${ }^{\mathrm{a}} \mathrm{QQFKK}$ K(Q) \\
\hline 1792.785 & 1792.825 & $402-415$ & (R)QFEEEKANWEAQQR(I) \\
\hline 1842.890 & 1842.942 & $46-62$ & (K)RGFEFTLM*VVGESGLGK(S) \\
\hline 1953.961 & 1953.982 & $25-41$ & (K)NLEGYVGFANLPNQVYR(K) \\
\hline 2082.036 & 2082.077 & $25-42$ & (K)NLEGYVGFANLPNQVYRK(S) \\
\hline 2097.988 & 2097.986 & $221-237$ & (K)IYEFPETDDEEENKLVK(K) \\
\hline 2607.417 & 2607.309 & $63-85$ & (K)STLINSLFLTDLYSPEYPGPSHR(I) \\
\hline
\end{tabular}

${ }^{a} \mathrm{M}^{*}$, Methionine sulfoxide; $\mathrm{C}^{\mathrm{a}}, S$-acrylamidocysteine. man, 1978; Matus et al., 1982; Adam and Matus, 1996), tubulin (Kelly and Cotman, 1978), a brain-specific intermediate filament protein termed $\alpha$-internexin, (Suzuki et al., 1997), and neurofilaments M and L (Kelly and Cotman, 1978). We identified one cytoskeletal protein that has not previously been reported in the PSD fraction, plectin (Fig. $6 A$ ). Plectin is a $300 \mathrm{kDa}$ protein that associates with intermediate filaments, actin, and tubulin (Wiche et al., 1991). We have not verified its location at synapses.

We identified a glycolytic enzyme, glyceraldehyde-3-phosphate dehydrogenase (G3PDH), previously reported to be in synaptosomes and in the PSD fraction (Rogalski-Wilk and Cohen, 1997; Wu et al., 1997; Moon et al., 1998). G3PDH binds to F-actin and may be anchored to the PSD via this interaction (Rogalski-Wilk and Cohen, 1997). We found Hsc-70, a constitutively expressed form of the $70 \mathrm{kDa}$ heat shock protein family (Kiang and Tsokos, 1998), that has previously been found in the PSD fraction (Suzuki et al., 1999) and was recently shown by immunocytochemistry to be present at synaptic junctions (S. N. Baek, I. S. Park, I. Jin, L. T. Schenker, M. B. Kennedy, and I. S. Moon, unpublished results).
Additional proteins identified in this study, but not previously reported in the PSD fraction (Fig. 6A), include contactin, a glycosylphosphatidylinositol-linked glycoprotein of the Ig superfamily (Reid et al., 1994; Langnaese et al., 1998), and KIAA0378, a protein of unknown function encoded by an open reading frame deposited in the human genomic database (Nagase et al., 1997).

Some of the proteins that we detected in this study are known to be, or appear to be, contaminants of the PSD fraction in the sense that they are not present at the postsynaptic site in fixed tissue. These include glial fibrillary acidic protein (Matus et al., 1980), which is not expressed in neurons, and synapsin, which is located principally in the presynaptic terminal (De Camilli et al., 1983). Synapsin may cofractionate with the PSD fraction by virtue of its affinity for CaM kinase II (Benfenati et al., 1992). The other presynaptic protein found in the PSD fraction, bassoon (tom Dieck et al., 1998), may also cofractionate anomalously with the PSD, or, more interestingly, it may be bound to junctional proteins in the PSD fraction that span the synaptic cleft in vivo. We found a group of mitochondrial proteins, including two inner membrane proteins, the ATP/ADP carrier (Fiore et al., 1998), 

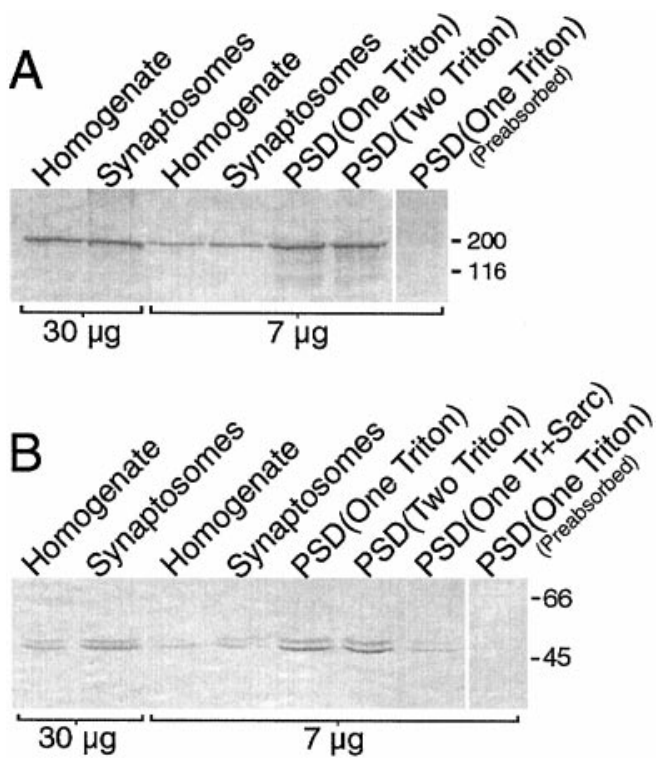

Figure 4. Myosin-Va and cdc10 are enriched in the PSD fraction. Immunoblots were prepared with $30 \mu \mathrm{g}$ (lanes 1,2) and $7 \mu \mathrm{g}$ (lanes 3-6) each of rat forebrain homogenate, synaptosome fraction, One-Triton fraction, and Two-Triton fraction, prepared as described in Materials and Methods. $B$ also includes $7 \mu \mathrm{g}$ of a One-Triton plus Sarcosyl PSD fraction in lane 7. Blots prepared with antibodies preabsorbed with their respective antigens are shown in the right lane. A, The myosin-Va protein bands were visualized with antibody $\mathrm{DB} 1 \mathrm{C}$ at $1: 1500$ dilution. $B$, The cdc10 protein bands were visualized with antibody L2 at 1:1000 dilution.

and creatine kinase (Bessman and Carpenter, 1985; Wallimann et al., 1989; Wyss et al., 1992), and the voltage-dependent anion channel, a mitochondrial pore-forming protein that plays a role in regulated movement of metabolites across the outer mitochondrial membrane (Dermietzel et al., 1994; Sampson et al., 1996; Moon et al., 1999). Mitochondria are a principal contaminant of the synaptosome fraction (Cohen et al., 1977), and thus fragments of mitochondrial membrane are likely to be the source of these proteins.

\section{DISCUSSION}

The postsynaptic density fraction has proven to be a valuable resource for identifying proteins that form the postsynaptic structural matrix and signaling systems. Identification of proteins in this fraction has facilitated development of models of synaptic structure, signaling systems, and plasticity (Sheng, 1996; Kennedy, 1997, 1998; Kornau et al., 1997). In the current study, we identified 31 proteins in the PSD fraction and assigned each protein to a specific protein band on SDS gels of the PSD fraction (Fig. 6). We found seven proteins that were not previously known to be constituents of the PSD fraction (Fig. 6A): the heavy chain of myosin-Va (Espreafico et al., 1992; Cheney et al., 1993), the septin protein cdc10 (Nakatsuru et al., 1994; Cooper and Kiehart, 1996), $\alpha$-actinin-1 (Youssoufian et al., 1990), contactin (Reid et al., 1994), the cytoskeletal protein plectin (Wiche et al., 1991), the mitochondrial ATP/ADP carrier protein (Fiore et al., 1998), and a protein encoded by an open reading frame deposited in the human genome database, KIAA0378 (Nagase et al., 1997). In addition, we confirmed the identity of 24 proteins that had previously been found to be components of the PSD by other methods (Fig. 6B).

In this study, proteins whose sequences are deposited in the public database were identified from three single lanes of $0.8-\mathrm{mm}$ - thick gels loaded with $\sim 30 \mu \mathrm{g}$ of protein per lane. The protein composition of postsynaptic densities may vary in different brain regions depending on the predominant neuronal cell type. The mass spectrometric method is sensitive enough that the protein compositions of PSD fractions isolated from particular brain regions, or after defined electrophysiological manipulations, could be analyzed and compared in their entirety. The amount of tissue needed for such experiments would be determined only by that required for a clean sucrose density fractionation during the preparation of the PSD fraction. The method cannot, however, be used to measure the precise stoichiometric relationships among proteins in a complex, because the sizes of the peptide mass peaks obtained in the mass scan are determined in part by the extent to which individual peptides can be volatilized.

Myosin-Va is slightly enriched in the PSD fraction (Fig. 4A) and located in synapses, dendrites, axons, and cell bodies of cultured hippocampal neurons (Fig. 5A). Expression of myosin-Va mRNA in the brain has been demonstrated by in situ hybridization (Mercer et al., 1991). Evidence is accumulating that myosin-Va functions as a motor that transports membrane vesicles along actin filaments (Brown, 1999). In one study, myosin-Va was shown to transport a population of vesicles derived from the endoplasmic reticulum (ER) (Tabb et al., 1998). Myosin-Va is also associated with presynaptic vesicles (Prekeris and Terrian, 1997; Evans et al., 1998). Function-blocking antibodies against myosin-Va completely inhibited the motility of these vesicles in vitro (Evans et al., 1998). Thus, in the presynaptic terminal, myosin-Va may be responsible for docking or transporting synaptic vesicles.

The importance of myosin-Va in dendrites is demonstrated in mice with "dilute" mutations that prevent the expression of myosin-Va and lead to severe neurological deficits culminating in death at $\sim 3$ weeks of age. The brains of the mutant mice appear normal on a gross level (Mercer et al., 1991). However, two recent studies demonstrate postsynaptic defects in dendritic spines of their Purkinje cells. In wild-type mice, branches of the smooth ER extend into the shaft of Purkinje neuron spines. Mice with dilute lethal $\left(\mathrm{d}^{1}\right)$ and dilute-opisthotonos (dop) mutations of myosin-Va are missing the ER in spines of Purkinje cells (Dekker-Ohno et al., 1996; Takagishi et al., 1996), suggesting that defects in transport or anchoring of ER-derived organelles within the spine might contribute to the phenotype associated with the mutations. Myosin-Va mutations in humans have been linked to Griscelli syndrome (Pastural et al., 1997), characterized by albinism, immune deficits, and seizures followed by death in the first decade. The phenotype displayed in these patients is reminiscent of the phenotype of myosin-Va-deficient mice and further demonstrates the importance of myosin-Va in the nervous system.

Myosin-Va was identified in the "first pass search" with peptides derived from the band at $190 \mathrm{kDa}$ (Fig. 6A), indicating that it is likely the most abundant protein in this band. Its abundance in the PSD fraction supports the idea that it may transport vesicles or proteins into spines and PSDs of forebrain neurons. Dendritic spines contain actin filaments that extend through the neck of the spine to the PSD and appear to make contact with the spine apparatus (Fifkova and Delay, 1982; Matus et al., 1982; Cohen et al., 1985; Morales and Fifkova, 1989). These filaments may provide a substrate for transport of postsynaptic proteins and organelles to the synapse by myosin-Va (Brown, 1999). Myosin-Va interacts directly with CaMKII (Costa et al., 1999), which is also an abundant PSD protein, and is phosphorylated by it (Coelho and Larson, 1993). Thus, activation of CaMKII by $\mathrm{Ca}^{2+}$ influx through NMDA receptors could potentially modulate myosin-Va 

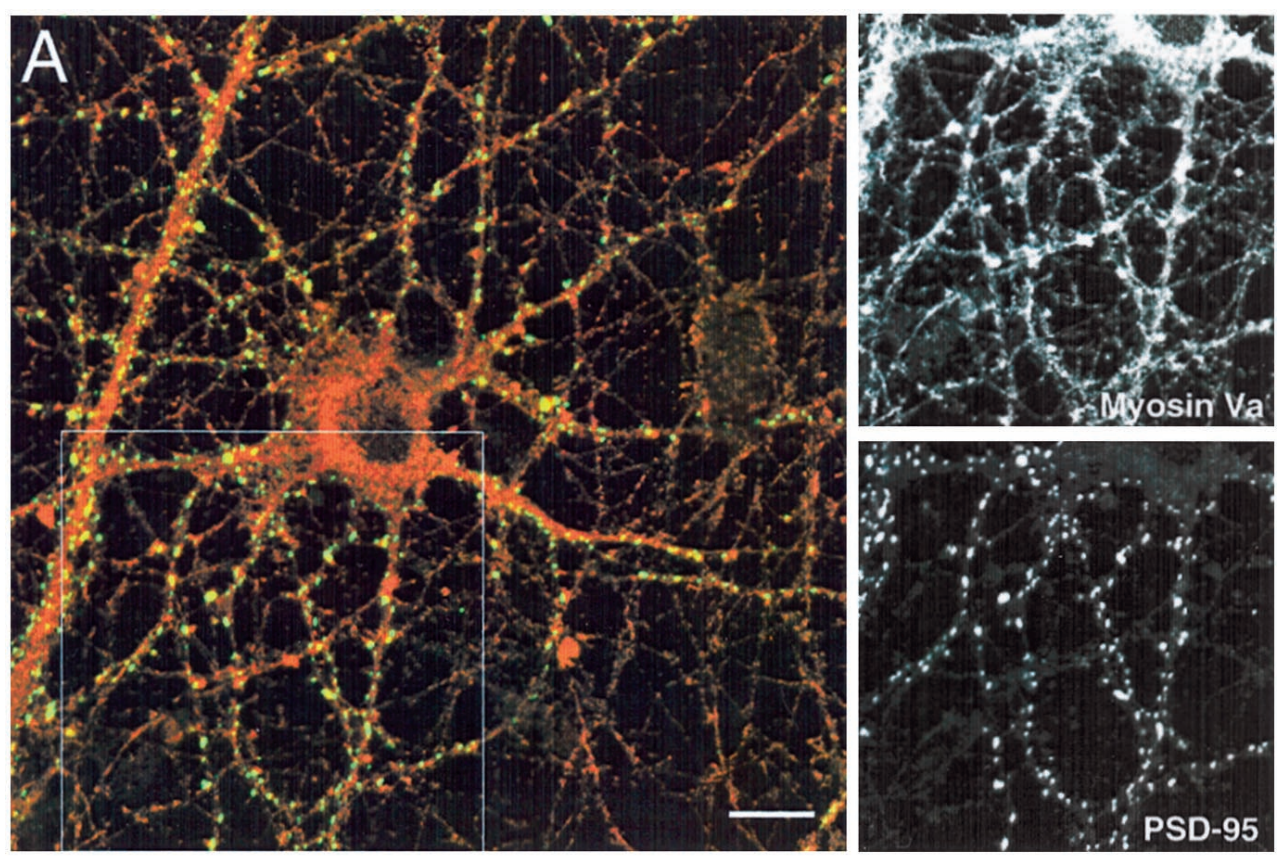

Figure 5. Immunocytochemical localization of myosin-Va and cdc10 in cultures of dissociated hippocampal neurons. Hippocampal neurons dissociated at E18 were grown in culture for $28 \mathrm{~d}$ and then fixed and double-immunostained as described in Materials and Methods. Images of the two fluorophors were colorized and combined (left). At right are the single images of the boxed regions. A, Immunocytochemical localization of myosin-Va and PSD-95. Red indicates Cy3 staining of myosin V, and green indicates FITC staining of PSD-95. Regions of overlap are yellow. Myosin-Va is distributed throughout cell bodies, dendrites, and axons and appears concentrated at synapses, where it colocalizes with PSD-95. $B$, Immunocytochemical localization of cdc10 and PSD-95. Red indicates Cy3 staining of cdc10, and green indicates FITC staining of PSD-95. CDC10 has a punctate distribution throughout the soma and dendrites. Some, but not all, of the cdc10 in dendrites colocalizes with PSD-95 at synapses. Scale bars, $10 \mu \mathrm{m}$.
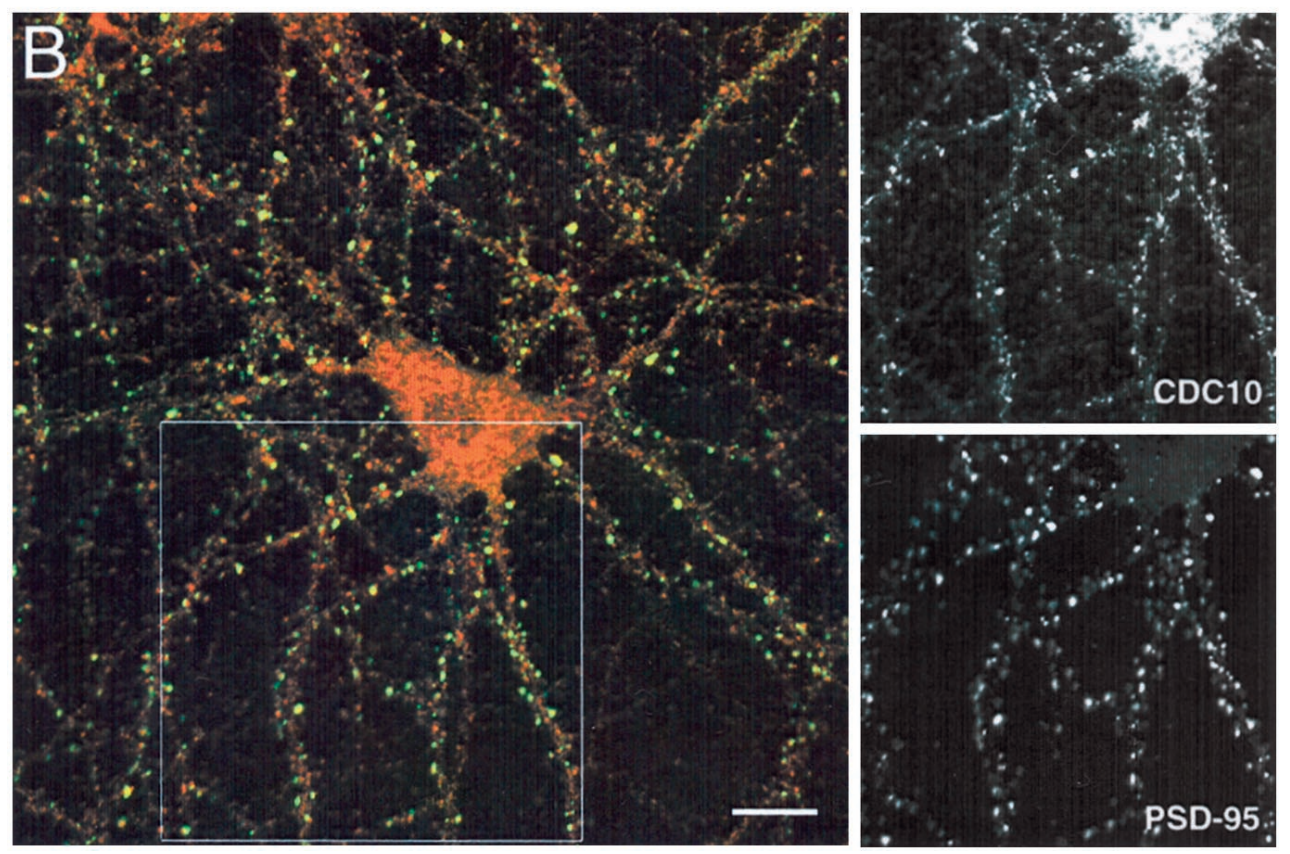

motor activity at the synapse. Naisbitt et al. (2000) report that the PSD-95/GKAP (guanylate kinase-associated protein) complex interacts with a light chain that is shared by dynein and myosin $\mathrm{V}$, providing additional evidence that myosin $\mathrm{V}$ may be a motor protein in the postsynaptic spine.

The second PSD protein that we studied in detail is the mammalian homolog of cdc10, a member of the septin family. We show that it partially colocalizes with PSD-95 at synapses in cultured hippocampal neurons (Fig. 5B). Cdc10 and the other septins were first identified as proteins that form heterooligomeric filaments that encircle the yeast bud neck (Byers and Goetsch, 1976; Haarer and Pringle, 1987; Ford and Pringle, 1991; Kim et al., 1991). Temperature-sensitive inactivation of any of the septins in yeast results in loss of neck filaments and causes cell cycle arrest and defects in bud growth and cytokinesis (Field and
Kellogg, 1999). In the absence of neck filaments, several kinases, and enzymes involved in cytokinesis fail to localize properly to the neck region, indicating that septins may form a scaffold for the assembly of protein complexes (Flescher et al., 1993; Chant et al., 1995; Field and Kellogg, 1999).

Septin homologs have been identified in Drosophila and mammals. They are generally associated with membranes in places where the membrane is undergoing remodeling, such as the site of bud emergence (Flescher et al., 1993; Chant et al., 1995), and extensions of neuronal growth cones (Neufeld and Rubin, 1994; Fares et al., 1995). Cdc10 was recently found to be associated with the exocyst complex in neurons (Hsu et al., 1998), which may be involved in vesicle fusion at the plasma membrane. The association of septins with a complex involved in membrane fusion may indicate that cdc10 plays a role in adding membrane to developing 


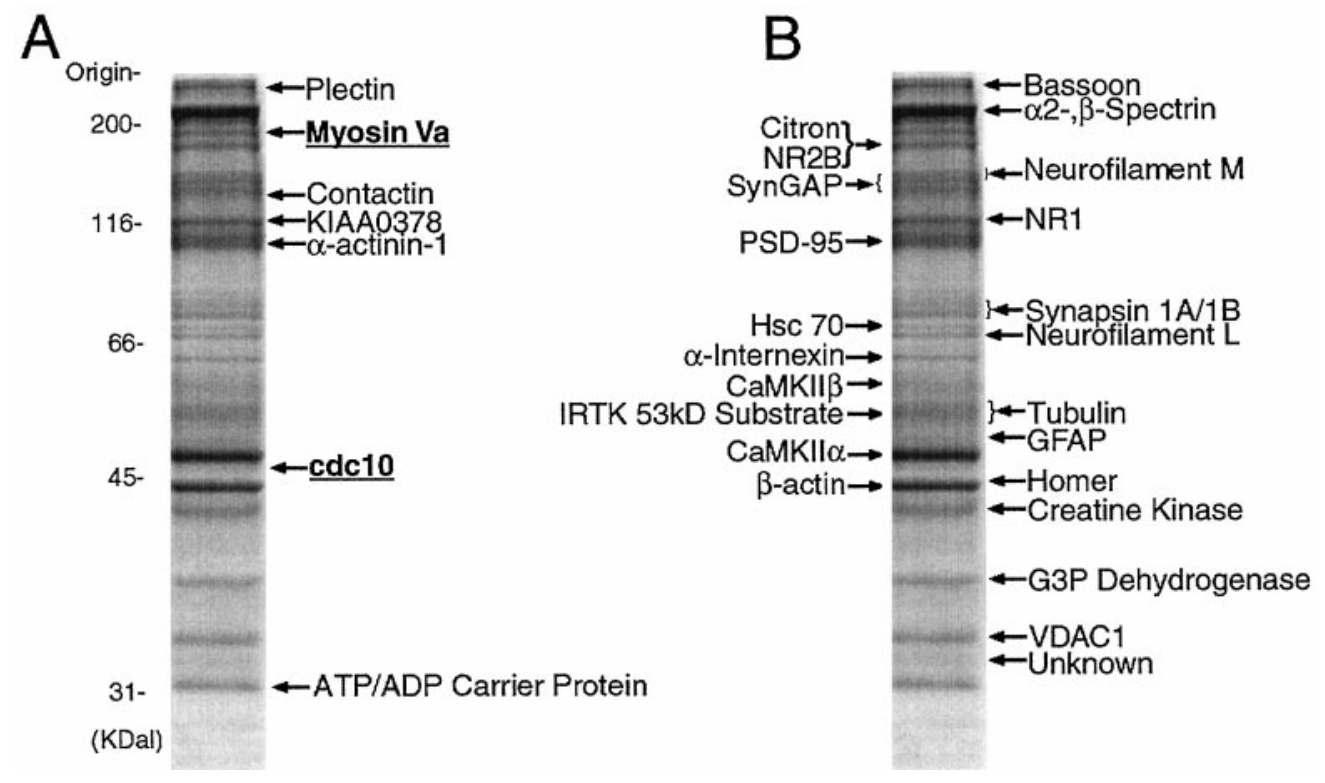

Figure 6. Proteins identified in the PSD fraction by MALDI-TOF MS. Thirty micrograms of protein from the Two-Triton PSD fraction were subjected to SDS-PAGE and stained with Coomassie blue. Individual protein bands were isolated, and the proteins in each band were identified by MALDI-TOF mass spectrometry as described in Materials and Methods. The positions of molecular weight standards are shown at left. A, Proteins identified for the first time in this study as constituents of the PSD fraction. The presence of myosin-Va and cdc10 (bold, underlined) at synaptic sites was verified in this study. $B$, Proteins identified in this study that were previously identified in the PSD fraction by other methods. neuronal processes at sites that could include synapses. Thus, in the PSD, septins may form a cytoskeletal structure for the assembly or addition of proteins at the postsynaptic membrane. The septin scaffold might then persist as part of the PSD in mature synapses. Septin polymerization is regulated by several signaling pathways during cytokinesis in yeast. Therefore, septin polymerization at the synapse may be dynamically regulated in response to synaptic signals.

The identification of $\alpha$-actinin- 1 in the PSD fraction illustrates the sensitivity of the mass spectrometric method. Four forms of human $\alpha$-actinin are known ( $\alpha$-actinins $1-4)$. The molecular masses of the peptides from the $\alpha$-actinin band unambiguously identify the isoform in the PSD fraction as a homolog of human $\alpha$-actinin-1. Wyszynski et al. (1997, 1998) identified human $\alpha$-actinin- 2 as an interactor with the NMDA receptor subunit NR1 in a yeast two-hybrid screen. Using antibodies against $\alpha$-actinin-2, they showed that it is concentrated in dendritic spines in hippocampal neurons. Human $\alpha$-actinin- 2 is $79 \%$ identical to human $\alpha$-actinin- 1 in amino acid sequence, and all known functional domains are conserved between the two proteins. Our data suggest that the rat form of $\alpha$-actinin that is present at postsynaptic sites is most homologous to human $\alpha$-actinin- 1 and not $\alpha$-actinin-2. However, $\alpha$-actinin- 1 and $\alpha$-actinin- 2 are likely to be functionally identical.

We did not find densin-180, which was previously identified in the PSD fraction by microsequencing and localizes at the synapse (Apperson et al., 1996). The presence of densin-180 may have been obscured in this study, because it comigrates with the NR2B subunit of the NMDA receptor (Moon et al., 1994; Apperson et al., 1996) and with citron (Zhang et al., 1999). In addition, densin-180 is extensively glycosylated (Apperson et al., 1996). The altered masses of tryptic peptides containing glycosyl groups may have precluded their identification by mass spectrometry.

Notably, several proteins originally identified by yeast twohybrid screens for proteins that interact with known PSD proteins were not found in the PSD fraction in our study, including shank (Naisbitt et al., 1999), yotaio (Lin et al., 1998), and GKAP (Kim et al., 1997; Naisbitt et al., 1997). Two homologs of PSD-95, SAP102 (Muller et al., 1996) and Chapsyn-110/PSD-93 (Brenman et al., 1996; Kim et al., 1996), were also not identified here, although they have been reported to be enriched in the postsynaptic density. Our inability to identify these proteins may reflect their relatively low abundance in the PSD fraction, although it is also possible that some of these proteins comigrate with more abundant PSD proteins and thus are difficult to detect by mass spectrometry.

It is important to note that low abundance of a protein in the PSD fraction does not necessarily indicate that it is absent from the PSD in vivo. It is quite likely that the association of some proteins with the native PSD is disrupted by extraction with Triton X-100 during the purification of the PSD fraction. Thus, additional methods, such as high-resolution immunolocalization, will be needed to ascertain the full protein composition of the postsynaptic lattice. Nonetheless, the identification of proteins in the PSD fraction has been a useful first step in understanding the organization of signaling molecules at the postsynaptic membrane.

\section{REFERENCES}

Abbott M-A, Wells DG, Fallon JR (1999) The insulin receptor tyrosine kinase substrate p58/53 and the insulin receptor are components of CNS synapses. J Neurosci 19:7300-7308.

Adam G, Matus A (1996) Role of actin in the organization of brain postsynaptic densities. Brain Res Mol Brain Res 43:246-250.

Apperson ML, Moon I-S, Kennedy MB (1996) Characterization of densin-180, a new brain-specific synaptic protein of the $O$-sialoglycoprotein family. J Neurosci 16:6839-6852.

Benfenati F, Valtorta F, Rubenstein JL, Gorelick FS, Greengard P, Czernik AJ (1992) Synaptic vesicle-associated $\mathrm{Ca}^{2+} /$ calmodulindependent protein kinase II is a binding-protein for synapsin I. Nature 359:417-420.

Bessman SP, Carpenter CL (1985) The creatine-creatine phosphate energy shuttle. Annu Rev Biochem 54:831-862.

Brakeman PR, Lanahan AA, O'Brien R, Roche K, Barnes CA, Huganir RL, Worley PF (1997) Homer: a protein that selectively binds metabotropic glutamate receptors. Nature 386:284-288.

Brenman JE, Christopherson KS, Craven SE, McGee AW, Bredt DS (1996) Cloning and characterization of postsynaptic density-93, a nitric oxide synthase interacting protein. J Neurosci 16:7407-7415.

Brewer GJ, Torricelli JR, Evege EK, Price PJ (1993) Optimized survival of hippocampal neurons in B27-supplemented Neurobasal ${ }^{\mathrm{TM}}$, a new serum-free medium combination. J Neurosci Res 35:567-576.

Brown SS (1999) Cooperation between microtubule- and actin-based motor proteins. Annu Rev Cell Dev Biol 15:63-80.

Byers B, Goetsch L (1976) A highly ordered ring of membraneassociated filaments in budding yeast. J Cell Biol 69:717-721. 
Carlin RK, Grab DJ, Cohen RS, Siekevitz P (1980) Isolation and characterization of postsynaptic densities from various brain regions: enrichment of different types of postsynaptic densities. J Cell Biol 86:831-843.

Carlin RK, Bartelt D, Siekevitz P (1983) Identification of fodrin as a major calmodulin-binding protein in postsynaptic density preparations. J Cell Biol 96:443-448.

Chant J, Mischke M, Mitchell E, Herskowitz I, Pringle JR (1995) Role of Bud3p in producing the axial budding pattern of yeast. J Cell Biol 129:767-778.

Chen H-J, Rojas-Soto M, Oguni A, Kennedy MB (1998) A synaptic Ras-GTPase activating protein (p135 SynGAP) inhibited by CaM Kinase II. Neuron 20:895-904.

Cheney RE, O’Shea MK, Heuser JE, Coelho MV, Wolenski JS, Espreafico EM, Forscher P, Larson RE, Mooseker MS (1993) Brain myosin- $\mathrm{V}$ is a two-headed unconventional myosin with motor activity. Cell 75:13-23.

Cho K-O, Hunt CA, Kennedy MB (1992) The rat brain postsynaptic density fraction contains a homolog of the Drosophila discs-large tumor suppressor protein. Neuron 9:929-942.

Coelho MV, Larson RE (1993) $\mathrm{Ca}^{2+}$-dependent phosphorylation of the tail domain of myosin- $\mathrm{V}$, a calmodulin-binding myosin in vertebrate brain. Braz J Med Biol Res 26:465-472.

Cohen RS, Blomberg F, Berzins K, Siekevitz P (1977) The structure of postsynaptic densities isolated from dog cerebral cortex I. overall morphology and protein composition. J Cell Biol 74:181-203.

Cohen RS, Chung SK, Pfaff DW (1985) Immunocytochemical localization of actin in dendritic spines of the cerebral cortex using colloidal gold as a probe. Cell Mol Neurobiol 5:271-284.

Cooper JA, Kiehart DP (1996) Septins may form a ubiquitous family of cytoskeletal filaments. J Cell Biol 134:1345-1348.

Costa MC, Mani F, Santoro Jr W, Espreafico EM, Larson RE (1999) Brain myosin- $\mathrm{V}$, a calmodulin-carrying myosin, binds to calmodulindependent protein kinase II and activates its kinase activity. J Biol Chem 274:15811-15819.

Cotman CW, Banker B, Churchill L, Taylor D (1974) Isolation of postsynaptic densities from rat brain. J Cell Biol 63:441-455.

De Camilli P, Harris Jr SM, Huttner WB, Greengard P (1983) Synapsin I (Protein I), a nerve terminal-specific phosphoprotein. II. Its specific association with synaptic vesicles demonstrated by immunocytochemistry in agarose-embedded synaptosomes. J Cell Biol 96:1355-1373.

Dekker-Ohno K, Hayasaka S, Takagishi Y, Oda S, Wakasugi N, Mikoshiba K, Inouye M, Yamamura H (1996) Endoplasmic reticulum is missing in dendritic spines of Purkinje cells of the ataxic mutant rat. Brain Res 714:226-230.

Dermietzel R, Hwang TK, Buettner R, Hofer A, Dotzler E, Kremer M, Deutzmann R, Thinnes FP, Fishman GI, Spray DC, Siemen D (1994) Cloning and in situ localization of a brain-derived porin that constitutes a large-conductance anion channel in astrocytic plasma membranes. Proc Natl Acad Sci USA 91:499-503.

Espreafico EM, Cheney RE, Matteoli M, Nascimento AAC, De Camilli PV, Larson RE, Mooseker MS (1992) Primary structure and cellular localization of chicken brain myosin-V (p190), an unconventional myosin with calmodulin light chains. J Cell Biol 119:1541-1557.

Evans LL, Lee AJ, Bridgman PC, Mooseker MS (1998) Vesicleassociated brain myosin- $\mathrm{V}$ can be activated to catalyze actin-based transport. J Cell Sci 111:2055-2066.

Fares H, Peifer M, Pringle JR (1995) Localization and possible functions of Drosophila septins. Mol Biol Cell 6:1843-1859.

Field CM, Kellogg D (1999) Septins: cytoskeletal polymers or signalling GTPases? Trends Cell Biol 9:387-394.

Fifkova E, Delay RJ (1982) Cytoplasmic actin in neuronal processes as a possible mediator of synaptic plasticity. J Cell Biol 95:345-350.

Fiore C, Trezeguet V, Le Saux A, Roux P, Schwimmer C, Dianoux AC, Noel F, Lauquin GJ, Brandolin G, Vignais PV (1998) The mitochondrial ADP/ATP carrier: structural, physiological and pathological aspects. Biochimie 80:137-150.

Flescher EG, Madden K, Snyder M (1993) Components required for cytokinesis are important for bud site selection in yeast. J Cell Biol 122:373-386.

Ford SK, Pringle JR (1991) Cellular morphogenesis in the Saccharomyces cerevisiae cell cycle: localization of the $\mathrm{CDC} 11$ gene product and the timing of events at the budding site. Dev Genet 12:281-292.

Glenney Jr JR, Glenney P, Weber K (1982) Erythroid spectrin, brain fodrin, and intestinal brush border proteins (TW-260/240) are related molecules containing a common calmodulin-binding subunit bound to a variant cell type-specific subunit. Proc Natl Acad Sci USA 79:4002-4005.

Haarer BK, Pringle JR (1987) Immunofluorescence localization of the Saccharomyces cerevisiae CDC12 gene product to the vicinity of the 10-nm filaments in the mother-bud neck. Mol Cell Biol 7:3678-3687.

Hsu SC, Hazuka CD, Roth R, Foletti DL, Heuser J, Scheller RH (1998) Subunit composition, protein interactions, and structures of the mammalian brain sec6/8 complex and septin filaments. Neuron 20:1111-1122.

Irie M, Hata Y, Takeuchi M, Ichtchenko A, Toyoda A, Hirao K, Takai Y, Rosahl TW, Sudhof TC (1997) Binding of neuroligins to PSD-95. Science 277:1511-1515.

Jeno P, Mini T, Moes S, Hintermann E, Horst M (1995) Internal sequences from proteins digested in polyacrylamide gels. Anal Biochem 224:75-82.

Jensen ON, Podtelejnikov AV, Mann M (1997) Identification of the components of simple protein mixtures by high-accuracy peptide mass mapping and database searching. Anal Chem 69:4741-4750.

Jensen ON, Podtelejnikov A, Mann M (1996) Delayed extraction improves specificity in database searches by MALDI peptide maps. Rapid Commun Mass Spectrom 68:850-858.

Jensen ON, Larsen MR, Roepstorff P (1998) Mass spectrometric identification and microcharacterization of proteins from electrophoretic gels: strategies and applications. Proteins [Suppl] 1-2:74-89.

Kato A, Ozawa F, Saitoh Y, Hirai K, Inokuchi K (1997) vesl, a gene encoding VASP/Ena family related protein, is upregulated during seizure, long-term potentiation and synaptogenesis. FEBS Lett 412:183-189.

Kato A, Ozawa F, Saitoh Y, Fukazawa Y, Sugiyama H, Inokuchi K (1998) Novel members of the Vesl/Homer family of PDZ proteins that bind metabotropic glutamate receptors. J Biol Chem 273:23969-23975.

Kelly PT, Cotman CW (1978) Synaptic proteins. Characterization of tubulin and actin and identification of a distinct postsynaptic density polypeptide. J Cell Biol 79:173-183.

Kelly PT, McGuinness TL, Greengard P (1984) Evidence that the major postsynaptic density protein is a component of a $\mathrm{Ca}^{2+} /$ calmodulindependent protein kinase. Proc Natl Acad Sci USA 81:945-949.

Kennedy MB (1993) The postsynaptic density. Curr Opin Neurobiol 3:732-737.

Kennedy MB (1997) The postsynaptic density at glutamatergic synapses. Trends Neurosci 20:264-268.

Kennedy MB (1998) Signal transduction molecules at the glutamatergic postsynaptic membrane. Brain Res Rev 26:243-257.

Kennedy MB, Bennett MK, Erondu NE (1983) Biochemical and immunochemical evidence that the "major postsynaptic density protein" is a subunit of a calmodulin-dependent protein kinase. Proc Natl Acad Sci USA 80:7357-7361.

Kennedy MB, Bennett MK, Bulleit RF, Erondu NE, Jennings VR, Miller SM, Molloy SS, Patton BL, Schenker LJ (1990) Structure and regulation of type II calcium/calmodulin-dependent protein kinase in central nervous system neurons. Cold Spring Harb Symp Quant Biol $55: 101-110$.

Kiang JG, Tsokos GC (1998) Heat shock protein $70 \mathrm{kDa}$ : molecular biology, biochemistry, and physiology. Pharmacol Ther 80:183-201.

Kim E, Niethammer M, Rothschild A, Jan YN, Sheng M (1995) Clustering of shaker-type $\mathrm{K}^{+}$channels by interaction with a family of membrane-associated guanylate kinases. Nature 378:85-88.

Kim E, Cho KO, Rothschild A, Sheng M (1996) Heteromultimerization and NMDA receptor-clustering activity of chapsyn-110, a member of the PSD-95 family of proteins. Neuron 17:103-113.

Kim E, Naisbitt S, Hsueh YP, Rao. A, Rothschild A, Craig AM, Sheng M (1997) GKAP, a novel synaptic protein that interacts with the guanylate kinase-like domain of the PSD-95/SAP90 family of channel clustering molecules. J Cell Biol 136:669-678.

Kim HB, Haarer BK, Pringle JR (1991) Cellular morphogenesis in the Saccharomyces cerevisiae cell cycle: localization of the CDC3 gene product and the timing of events at the budding site. J Cell Biol 112:535-544.

Kim JH, Liao D, Lau L-F, Huganir RL (1998) SynGAP: a synaptic RasGAP that associates with the PSD-95/SAP90 protein family. Neuron 20:683-691.

Kistner U, Wenzel BM, Veh RW, Cases-Langhoff C, Garner AM, Appeltauer U, Voss B, Gundelfinger ED, Garner CC (1993) SAP90, a rat presynaptic protein related to the product of the Drosophila tumor suppressor gene $d l g$-A. J Biol Chem 268:4580-4583. 
Kornau H-C, Schenker LT, Kennedy MB, Seeburg PH (1995) Domain interaction between NMDA receptor subunits and the postsynaptic density protein PSD-95. Science 269:1737-1740.

Kornau H-C, Seeburg PH, Kennedy MB (1997) Interaction of ion channels and receptors with PDZ domain proteins. Curr Opin Neurobiol 7:368-373.

Kozak M (1989) The scanning model for translation: an update. J Cell Biol 108:229-241.

Kozak M (1997) Recognition of AUG and alternative initiator codons is augmented by $\mathrm{G}$ in position +4 but is not generally affected by the nucleotides in positions +5 and +6 . EMBO J 16:2482-2492.

Langnaese K, Mummery R, Gundelfinger ED, Beesley PW (1998) Immunoglobulin superfamily members gp65 and gp55: tissue distribution of glycoforms. FEBS Lett 429:284-288.

Lau LF, Mammen A, Ehlers MD, Kindler S, Chung WJ, Garner CC, Huganir RL (1996) Interaction of the $N$-methyl-D-aspartate receptor complex with a novel synapse-associated protein, sap102. J Biol Chem 271:21622-21628.

Lin JW, Wyszynski M, Madhavan R, Sealock R, Kim JU, Sheng M (1998) Yotiao, a novel protein of neuromuscular junction and brain that interacts with specific splice variants of NMDA receptor subunit NR1. J Neurosci 18:2017-2027.

Matus A, Pehling G, Ackermann M, Maeder J (1980) Brain postsynaptic densities: their relationship to glial and neuronal filaments. J Cell Biol 87:346-359.

Matus A, Ackermann M, Pehling G, Byers HR, Fujiwara K (1982) High actin concentrations in brain dendritic spines and postsynaptic densities. Proc Natl Acad Sci USA 79:7590-7594.

Mercer JA, Seperack PK, Strobel MC, Copeland NG, Jenkins NA (1991) Novel myosin heavy chain encoded by murine dilute coat colour locus. Nature [erratum (1991) 352:547] 349:709-713.

Miller SG, Kennedy MB (1985) Distinct forebrain and cerebellar isozymes of type II $\mathrm{Ca}^{2+} /$ calmodulin-dependent protein kinase associate differently with the postsynaptic density fraction. J Biol Chem 260:9039-9046.

Moon IS, Apperson ML, Kennedy MB (1994) The major tyrosinephosphorylated protein in the postsynaptic density fraction is $N$-methylD-aspartate receptor subunit 2B. Proc Natl Acad Sci USA 91:3954-3958.

Moon JI, Dae Kim J, Wook Jung Y, Hyun Ko B, Jin I, Moon IS (1998) Identification of glyceraldehyde-3-phosphate dehydrogenase by protein sequencing in the rat postsynaptic density fraction. Mol Cells 8:359-365.

Moon JI, Jung YW, Ko BH, De Pinto V, Jin I, Moon IS (1999) Presence of a voltage-dependent anion channel 1 in the rat postsynaptic density fraction. NeuroReport 10:443-447.

Morales M, Fifkova E (1989) In situ localization of myosin and actin in dendritic spines with the immunogold technique. J Comp Neurol 279:666-674.

Muller BM, Kistner U, Kindler S, Chung WJ, Kuhlendahl S, Fenster SD, Lau LF, Veh RW, Huganir RL, Gundelfinger ED, Garner CC (1996) Sap102, a novel postsynaptic protein that interacts with NMDA receptor complexes in-vivo. Neuron 17:255-265.

Nagase T, Ishikawa K, Seki N, Nakajima D, Ohira M, Miyajima N, Kotani H, Nomura N, Ohara O (1997) Prediction of the coding sequences of unidentified human genes. VII. The complete sequences of 100 new cDNA clones from brain which can code for large proteins in vitro. DNA Res 4:141-150.

Naisbitt S, Kim E, Weinberg RJ, Rao A, Yang FC, Craig AM, Sheng M (1997) Characterization of guanylate kinase-associated protein, a postsynaptic density protein at excitatory synapses that interacts directly with postsynaptic density-95/synapse-associated protein 90 . J Neurosci 17:5687-5696.

Naisbitt S, Kim E, Tu JC, Xiao B, Sala C, Valtschanoff J, Weinberg RJ, Worley PF, Sheng M (1999) Shank, a novel family of postsynaptic density proteins that binds to the NMDA receptor/PSD-95/GKAP complex and cortactin. Neuron 23:569-582.

Naisbitt S, Valtschanoff J, Allison DW, Sala C, Kim E, Craig AM, Weinberg RJ, Sheng M (2000) Interaction of the PSD-95/GKAP complex with a light chain shared by dynein and myosin V. J Neurosci, in press.

Nakatsuru S, Sudo K, Nakamura Y (1994) Molecular cloning of a novel human cDNA homologous to CDC10 in Saccharomyces cerevisiae. Biochem Biophys Res Commun 202:82-87.

Neufeld TP, Rubin GM (1994) The Drosophila peanut gene is required for cytokinesis and encodes a protein similar to yeast putative bud neck filament proteins. Cell 77:371-379.

Ou SK, Hwang JM, Patterson PH (1993) A modified method for obtaining large amounts of high-titer polyclonal ascites fluid. J Immunol Methods 165:75-80.

Pastural E, Barrat FJ, Dufourcq-Lagelouse R, Certain S, Sanal O, Jabado N, Seger R, Griscelli C, Fischer A, de Saint Basile G (1997) Griscelli disease maps to chromosome $15 \mathrm{q} 21$ and is associated with mutations in the myosin-Va gene. Nat Genet 16:289-292.

Peterson GL (1983) Determination of total protein. Methods Enzymol 91:95-119.

Prekeris R, Terrian DM (1997) Brain myosin V is a synaptic vesicleassociated motor protein: evidence for a $\mathrm{Ca} 2+$-dependent interaction with the synaptobrevin-synaptophysin complex. J Cell Biol 137:1589-1601.

Reid RA, Bronson DD, Young KM, Hemperly JJ (1994) Identification and characterization of the human cell adhesion molecule contactin. Brain Res Mol Brain Res 21:1-8.

Rogalski-Wilk AA, Cohen RS (1997) Glyceraldehyde-3-phosphate dehydrogenase activity and F-actin associations in synaptosomes and postsynaptic densities of porcine cerebral cortex. Cell Mol Neurobiol 17:51-70.

Rosenfeld J, Capdevielle J, Guillemot JC, Ferrara P (1992) In-gel digestion of proteins for internal sequence analysis after one- or twodimensional gel electrophoresis. Anal Biochem 203:173-179.

Sampson MJ, Lovell RS, Craigen WJ (1996) Isolation, characterization, and mapping of two mouse mitochondrial voltage-dependent anion channel isoforms. Genomics 33:283-288.

Seperack PK, Mercer JA, Strobel MC, Copeland NG, Jenkins NA (1995) Retroviral sequences located within an intron of the dilute gene alter dilute expression in a tissue-specific manner. EMBO J 14:2326-2332.

Sheng M (1996) PDZs and receptor/channel clustering: rounding up the latest suspects. Neuron 17:575-578.

Shevchenko A, Jensen ON, Podtelejnikov AV, Sagliocco F, Wilm M, Vorm O, Mortensen P, Shevchenko A, Boucherie H, Mann M (1996a) Linking genome and proteome by mass spectrometry: large-scale identification of yeast proteins from two dimensional gels. Proc Natl Acad Sci USA 93:14440-14445.

Shevchenko A, Wilm M, Vorm O, Mann M (1996b) Mass spectrometric sequencing of proteins from silver stained polyacrylamide gels. Anal Chem 68:850-858.

Siekevitz P (1985) The postsynaptic density: a possible role in longlasting effects in the central nervous system. Proc Natl Acad Sci USA 82:3494-3498.

Soulier S, Vilotte JL (1998) Sequence of murine CDC10 cDNA, gene organization and expression analysis. Biochim Biophys Acta 1442: 339-346.

Suzuki T, Mitake S, Okumura-Noji K, Shimizu H, Tada T, Fujii T (1997) Excitable membranes and synaptic transmission: postsynaptic mechanisms. Localization of alpha-internexin in the postsynaptic density of the rat brain. Brain Res 765:74-80.

Suzuki T, Usuda N, Murata S, Nakazawa A, Ohtsuka K, Takagi H (1999) Presence of molecular chaperones, heat shock cognate (Hsc) 70 and heat shock proteins (Hsp) 40, in the postsynaptic structures of rat brain. Brain Res 816:99-110.

Tabb JS, Molyneaux BJ, Cohen DL, Kuznetsov SA, Langford GM (1998) Transport of ER vesicles on actin filaments in neurons by myosin V. J Cell Sci 111:3221-3234.

Takagishi Y, Oda S, Hayasaka S, Dekker-Ohno K, Shikata T, Inouye M, Yamamura H (1996) The dilute-lethal (dl) gene attacks a Ca2+ store in the dendritic spine of Purkinje cells in mice. Neurosci Lett 215:169-172.

tom Dieck S, Sanmarti-Vila L, Langnaese K, Richter K, Kindler S, Soyke A, Wex H, Smalla KH, Kampf U, Franzer JT, Stumm M, Garner CC, Gundelfinger ED (1998) Bassoon, a novel zinc-finger CAG/glutaminerepeat protein selectively localized at the active zone of presynaptic nerve terminals. J Cell Biol 142:499-509.

Tu JC, Xiao B, Yuan JP, Lanahan AA, Leoffert K, Li M, Linden DJ, Worley PF (1998) Homer binds a novel proline-rich motif and links group 1 metabotropic glutamate receptors with IP3 receptors. Neuron 21:717-726.

Tu JC, Xiao B, Naisbitt S, Yuan JP, Petralia RS, Brakeman P, Doan A, Aakalu VK, Lanahan AA, Sheng M, Worley PF (1999) Coupling of mGluR/Homer and PSD-95 complexes by the Shank family of postsynaptic density proteins. Neuron 23:583-592. 
Vorm O, Roepstorff P, Mann M (1994) Matrix surfaces made by fast evaporation yield improved resolution and very high sensitivity in MALDI TOF. Anal Chem 66:3281-3287.

Wallimann T, Schnyder T, Schlegel J, Wyss M, Wegmann G, Rossi AM, Hemmer W, Eppenberger HM, Quest AF (1989) Subcellular compartmentation of creatine kinase isoenzymes, regulation of CK and octameric structure of mitochondrial CK: important aspects of the phosphoryl-creatine circuit. Prog Clin Biol Res 315:159-176.

Wiche G, Becker B, Luber K, Weitzer G, Castañon MJ, Hauptmann R, Stratowa C, Stewart M (1991) Cloning and sequencing of rat plectin indicates a $466-\mathrm{kD}$ polypeptide chain with a three-domain structure based on a central alpha-helical coiled coil. J Cell Biol 114:83-99.

Wu K, Aoki C, Elste A, Rogalski-Wilk AA, Siekevitz P (1997) The synthesis of ATP by glycolytic enzymes in the postsynaptic density and the effect of endogenously generated nitric oxide Proc Natl Acad Sci USA [erratum (1998) 95:2714] 94:13273-13278.

Wyss M, Smeitink J, Wevers RA, Wallimann T (1992) Mitochondrial creatine kinase: a key enzyme of aerobic energy metabolism. Biochim Biophys Acta 1102:119-166.
Wyszynski M, Lin J, Rao A, Nigh E, Beggs AH, Craig AM, Sheng M (1997) Competitive binding of $\alpha$-actinin and calmodulin to the NMDA receptor. Nature 385:439-442.

Wyszynski M, Kharazia V, Shanghvi R, Rao A, Beggs AH, Craig AM, Weinberg R, Sheng M (1998) Differential regional expression and ultrastructural localization of $\alpha$-Actinin-2, a putative NMDA receptoranchoring protein, in rat brain. J Neurosci 18:1383-1392.

Yeh TC, Ogawa W, Danielsen AG, Roth RA (1996) Characterization and cloning of a $58-53 \mathrm{kDa}$ substrate of the insulin receptor tyrosine kinase. J Biol Chem 271:2921-2928.

Youssoufian H, McAfee M, Kwiatkowski DJ (1990) Cloning and chromosomal localization of the human cytoskeletal alpha-actinin gene reveals linkage to the beta-spectrin gene. Am J Hum Genet 47:62-71.

Zhang W, Vazquez L, Apperson M, Kennedy MB (1999) Citron binds to PSD-95 at glutamatergic synapses on inhibitory neurons in the hippocampus. J Neurosci 19:96-108.

Ziff EB (1997) Enlightening the postsynaptic density. Neuron 19:11631174. 